\title{
Are Booster Seats More Effective than Child Safety Seats or Seat Belts at Reducing Traffic Fatalities among Children?
}

\section{Authors: D. Mark Anderson and Sina Sandholt}

This is the author's final version. The article has been accepted for publication in American Journal of Health Economics. The final version can be found at doi:10.1162/ajhe a 00114.

Anderson, D. Mark, and Sina Sandholt. "Are Booster Seats More Effective than Child Safety Seats or Seat Belts at Reducing Traffic Fatalities among Children?." American Journal of Health Economics 5, no. 1 (January 2019): 42-64. DOI:10.1162/ajhe_a_00114. 


\title{
Are Booster Seats More Effective than Child Safety Seats or Seat Belts at Reducing Traffic Fatalities among Children?
}

\author{
D. Mark Anderson* \\ Department of Agricultural Economics and Economics \\ Montana State University and IZA \\ Email: dwight.anderson@montana.edu \\ Sina Sandholt \\ School of International and Public Affairs \\ Columbia University \\ Email: sina.sandholt@gmail.com
}

November 2017

\begin{abstract}
In an effort to increase booster seat use among children, the National Highway Traffic Safety Administration is encouraging state legislators to promote stricter booster seat laws, yet there is a paucity of information on booster seat efficacy relative to other forms of restraint. Using data from the Fatality Analysis Reporting System for the period 2008-2016, the current study examines the effectiveness of booster seats relative to child safety seats and adult seat belts. For children 2 to 5 years of age, we find some evidence to suggest that booster seats are the least effective form of restraint. For children 6 to 9 years of age, all three forms of restraint appear equally effective.
\end{abstract}

JEL Codes: I12, I18

Key Words: Booster Seats, Child Safety Seats, Traffic Fatalities

\footnotetext{
* Corresponding author. Address: Department of Agricultural Economics and Economics, Montana State University, P.O. Box 172920, Bozeman, MT 59717-2920. Phone: 406-366-0921. Email: dwight.anderson@montana.edu.

We thank Dean Anderson, Chad Cotti, Chris Stoddard, Carly Urban, and participants at the 2015 Southern Economic Association Annual Meeting for comments and suggestions. Partial support for this research came from a Eunice Kennedy Shriver National Institute of Child Health and Human Development research infrastructure grant, R24 HD042828, to the Center for Studies in Demography and Ecology at the University of Washington.
} 


\section{INTRODUCTION}

Motor vehicle accidents are the leading cause of injury-related deaths among children ages one and older in the United States (Decina et al. 2008; Centers for Disease Control and Prevention 2015). To curb these high fatality rates, decades of legislation have taken aim at protecting child passengers. Early laws during the 1970s and 1980s mandated the use of child safety seats (Bae et al. 2014). More recently, states have focused on older children by implementing booster seat laws (Decina et al. 2008). ${ }^{1}$ Booster seats are intended for children who have outgrown their child safety seat but are too small to use a standard adult seat belt. While there is a large literature on the effectiveness of child safety seats (see, e.g., Kahane 1986; Partyka 1988; Hertz 1996; Elliot et al. 2006; Levitt 2008; Rice and Anderson 2009), little is known about the potential life-saving effects of boosters. Our goal is to provide the first credible estimates on the effectiveness of booster seats at reducing traffic fatalities among children.

To estimate the relationship between booster seat use and the likelihood of fatality in a motor vehicle accident, we use data from the Fatality Analysis Reporting System (FARS) for the period 2008-2016 and employ the sample selection correction developed by Levitt and Porter (2001). The sample selection correction addresses the fact that restraint use likely influences whether an observation is included in a data set on traffic fatalities. For children ages 2 through 9, our results generally suggest that booster seats are no more effective at decreasing the

\footnotetext{
${ }^{1}$ Booster seat laws vary along several margins. For example, the ages covered by these laws range from 5 to 8 and some states specify weight and/or height thresholds for which a booster seat is required. The enforcement of booster seat laws also differs widely. Similar to seat belt laws, some booster seat laws are primary; police may stop vehicles solely for violating the law. In other states, booster seat laws are secondary; police must have an additional reason to make a stop. Fines range from $\$ 5$ to $\$ 500$ and some states count points against a driver's license or insurance for noncompliance (Decina et al. 2008). Florida is the most recent state to pass a booster seat law. As of January 1, 2015, children in Florida are required to ride in a crash-tested, federally approved car or booster seat until the age of 6 (Jacobson 2015). To date, South Dakota is the only state without booster seat legislation (Governors Highway Safety Association 2016).
} 
probability of fatality than are child safety seats or standard seat belts. For the younger children in our sample (2- to 5-year-olds), we find some evidence consistent with the notion that booster seats are the least effective form of restraint. However, because the coefficient estimate on our booster seat indicator is measured imprecisely in our preferred specification for this age group, we cannot formally reject the null hypotheses that booster seats and child safety seats or booster seats and seat belts are equally effective at conventional levels of statistical significance.

\section{BACKGROUND}

Booster seats have become increasingly popular for children who have outgrown their child safety seat. In 1995, only 6 percent of children weighing 40 to 60 pounds used a child safety seat or a booster seat (Decina and Knoebel 1997). In 2013, 44 percent of children weighing 40 to 60 pounds and 46 percent of children 4 to 7 years of age rode in a booster (Pickrell and Choi 2014). According to Arbogast et al. (2009), booster seats have become the most common form of restraint among 4- to 5-year-olds. The AAP has even included questions on booster seat use in their physician guidelines for well-child visits (Hagan et al. 2008).

Booster seats are made to improve seat belt fit by raising the position of the child and, for most models, by altering the route of the seat belt. Anatomically proper fit is characterized by belt placement where the force of the belt is directed onto the skeleton as opposed to soft tissues (Reed et al. 2013). If seat belts are not positioned correctly, they can slice into internal organs (O'Donnell 2011). During a crash, the lap portion of the belt should engage with the front of the pelvis and the shoulder portion of the belt should engage with the clavicle (Reed et al. 2013). ${ }^{2}$

\footnotetext{
${ }^{2}$ Pediatricians recommend that parents use the following five-step test to determine if their child is too small for an adult seat belt:
}

1.) Does the child sit all the way back against the auto seat? 
Because belt positioning is critical for the safety of the child, premature graduation from a child safety seat to a booster seat or from a booster seat to a seat belt could be hazardous. ${ }^{3}$ Likewise, research suggests that it is unsafe to keep a child in a particular restraint device after they have outgrown it (Pickrell and Choi 2013). Even if a child is of the appropriate age and size for a booster seat, parental error during the installation process can also complicate matters. According to the Insurance Institute for Highway Safety, many parents do not understand that the purpose of a booster seat is to ensure proper seat belt fit (O'Donnell 2011). A recent study by the NHTSA found that roughly 10 percent of children in booster seats had the lap belt sitting too high, across the child's stomach (Greenwell 2015). The same study found that over 50 percent of child safety seats were used incorrectly (Greenwell 2015).

\section{PREVIOUS STUDIES}

Since Peltzman's (1975) seminal work, economists have been interested in traffic safety restraint devices and the legislation governing their use. ${ }^{4}$ The majority of this research has focused on seat belts. For instance, Levitt and Porter (2001), Cohen and Einav (2003), and Sen

2.) Do the child's knees bend comfortably at the edge of the auto seat?

3.) Does the belt cross the shoulder between the neck and the arm?

4.) Is the lap belt as low as possible, touching the thighs?

5.) Can the child stay seated like this for the whole trip?

If parents answer "no" to any of these questions, then a booster seat is recommended (Pediatric Center 2005).

${ }^{3}$ Recently, car seat companies have developed safety seats with 5-point harnesses to accommodate older children. Typically, these types of car seats are significantly more expensive than belt-positioning boosters. For instance, Evenflo, a popular car seat brand, sells belt-positioning booster seats ranging in price from $\$ 25$ to $\$ 85$. Their 5point-harness seats, designed to carry children up to $65 \mathrm{lbs}$., start at $\$ 150$ (www.evenflo.com). Britax, another popular car seat brand, sells their belt-positioning booster for $\$ 160$, while their 5-point-harness seats for older children start at $\$ 230$ (us.britax.com).

${ }^{4}$ Peltzman (1975) introduced the concept that benefits from vehicle safety regulation may be offset by a compensating increase in risky driving behaviors. 
and Mizzen (2007) studied the relationship between seat belt use and the risk of traffic fatality. ${ }^{5}$

Relatedly, Sen (2001), Morrisey and Grabowski (2005), and Carpenter and Stehr (2008)

estimated the relationship between mandatory seat belt laws and traffic fatality rates in the

United States. ${ }^{6}$ In general, these studies support the notion that seat belts and the laws mandating

their use promote driver safety. Other research on traffic safety devices has studied the effects of air bags (Peterson et al. 1995; Levitt and Porter 2001), motorcycle helmets (Sass and Leigh

1991; Sass and Zimmerman 2000; Dee 2009; Dickert-Conlin et al. 2011), and vehicle safety

inspections (Merrell et al. 1999). ${ }^{7}$

The literature on child restraint devices is quite large. However, most of the research has focused on child safety seats, not boosters. Moreover, the existing booster seat studies come with significant drawbacks. For instance, they either use crash data from only one state (Anderson et al. 2017), are restricted by a small sample size (Ma et al. 2013), rely on older data from periods when booster seat use was rare (Durbin et al. 2003) ${ }^{8}$, or focus only on trafficrelated injuries (Durbin et al. 2003; Arbogast et al. 2009; Anderson et al. 2017). ${ }^{9}$ Given the

\footnotetext{
${ }^{5}$ Levitt and Porter (2001) found that wearing a seat belt reduces the likelihood of death by approximately 60 percent. Cohen and Einav (2003) estimated the relationship between seat belt use and traffic fatality rates at the state level, using mandatory seat belt laws as instrumental variables. Sen and Mizzen (2007) used province-level data from Canada and a similar empirical strategy. Both studies found evidence of a negative relationship between seat belt usage and traffic fatality rates.

${ }^{6}$ Sen (2001) found that mandatory seat belt legislation was associated with a 21 percent decline in driver fatalities. Morrisey and Grabowski (2005) focused on older drivers and found that primary seatbelt laws reduced fatalities by roughly 13 percent for 65 to 74 year olds. Carpenter and Stehr (2008) found that primary seatbelt laws reduced traffic fatalities among individuals 14 to 18 years of age by approximately 8 percent.

${ }^{7}$ Economists have studied a wide array of policies that influence traffic fatality rates. For example, research has focused on alcohol and drug policies (Dee 2001; Carpenter and Dobkin 2009; Grant 2010; Anderson et al. 2013), automobile insurance and accident liability laws (Cohen and Dehejia 2004), graduated driver licensing laws (Dee et al. 2005), minimum wage laws (Adams et al. 2012; Sabia et al. 2014), smoking bans (Adams and Cotti 2008), and texting bans (Abouk and Adams 2013).

${ }^{8}$ Durbin et al. (2003) observed only 4 percent of 6- and 7-year-olds riding in booster seats in their data.

${ }^{9}$ Due to a relatively small number of fatalities in their data, Anderson et al. (2017) considered a serious injury category that combined incapacitating and fatal injuries.
} 
limitations of these papers, credible estimates of the relationship between booster seat use and the probability of fatality remain absent from the literature. ${ }^{10}$

Using FARS data for the period 1975-2003 and the sample selection correction developed in Levitt and Porter (2001), which we describe in more detail below, Levitt (2008) found that child restraint devices do not provide a noticeable safety improvement over the use of standard adult seat belts for children ages 2 through $6 .{ }^{11}$ Due to a recent innovation in the FARS that was unavailable to Levitt (2008), we create separate indicators for child safety and booster seats. Prior to 2008, the FARS lumped both types of restraint into the same category. Distinguishing between restraint types is vital as booster seats are rapidly gaining in popularity, especially for use among older children. For Levitt's (2008) period of interest, children 6 years of age and older were rarely restrained by a device other than a standard seat belt. ${ }^{12}$

\footnotetext{
${ }^{10}$ The literature on booster seat use and traffic-related injuries is mixed. Using data from insurance claims and telephone surveys, Durbin et al. (2003) and Arbogast et al. (2009) found that booster seats were associated with added safety benefits relative to standard seat belts. Using data from the National Automotive Sampling System, Ma et al. (2013) found that children who used booster seats were more likely to experience neck and thorax injuries than children who used seat belts alone. Anderson et al. (2017) used crash data from the Washington State Department of Transportation and found that booster use was associated with a reduction in the odds of any injury relative to riding in a seat belt alone. They found that the risk of experiencing an incapacitating/fatal injury, however, was not associated with booster use.

${ }^{11}$ Jones and Ziebarth (2016) successfully replicated Levitt's (2008) findings for the period 1975-2003 and showed that they hold for the years 2004-2011. However, they did not exploit the recent innovation in the FARS that allows researchers to discern between child safety seats and booster seats. Doyle and Levitt (2010) used data from the General Estimates Survey, the New Jersey Department of Transportation, and the Wisconsin Crash Outcome Data Evaluation System to estimate the relationship between child restraint device use and traffic-related injuries. For the two most serious injury categories ("fatal/incapacitating" and "nonincapacitating" injuries), they found no difference between child restraint devices and standard seat belts. For the least serious injury category ("possible" injuries), they found that child restraint devices outperformed seat belts. Similar to Levitt (2008), they were unable to distinguish between different types of child restraint devices.

${ }^{12}$ In the FARS data, less than 1 and 8 percent of 6-year-olds were restrained by a device other than a standard seat belt in 2000 and 2003, respectively. By 2008, over 30 percent of 6-year-olds were restrained by a device other than a standard seat belt.
} 


\section{DATA AND EMPIRICAL STRATEGY}

We use annual data from the Fatality Analysis Reporting System for the period 2008-

2016 to examine the relationship between booster seat use and the likelihood of fatality. ${ }^{13}$ These data come from the NHTSA and represent a census of all fatal injuries resulting from motor vehicle accidents in the United States. ${ }^{14}$

We restrict the data set along several margins. First, we limit the sample to children 2 to 9 years of age. The overwhelming majority of children under the age of 2 in the data are in child safety seats or ride unrestrained. Children over the age of 9 are almost exclusively in standard adult seat belts or ride unrestrained. Second, we limit the sample to occupants of passenger cars and light trucks. ${ }^{15}$ This effectively excludes accidents where the only fatalities are to pedestrians, motorcyclists, or passengers of large trucks (e.g., moving trucks or semis), buses, or other nonstandard vehicles (e.g., limousines, motor homes, ATVs). Lastly, we drop individuals from the sample with unknown or missing information on age, restraint type, or injury severity.

Table 1 provides descriptive statistics on fatal injuries by restraint type. For children 2 to 9 years of age, roughly 30 percent who ride unrestrained die, and this estimate is slightly higher for the younger children in the sample. Fatality rates for children in booster seats are higher than

\footnotetext{
${ }^{13}$ Information on the details of each accident comes from a variety of sources: police reports, driver licensing files, vehicle registration files, state highway department data, emergency medical services records, medical examiner reports, toxicology reports, and death certificates. Additional information on how the FARS data are collected is available at: http://www.nhtsa.gov/FARS.

${ }^{14}$ An obvious limitation of the FARS data is that they do not include information on non-fatal crashes. To explore differences between children involved in fatal versus non-fatal crashes, we called upon crash data from the Washington State Department of Transportation (DOT) for the period 2002 through 2015. Children 2 to 9 years of age involved in fatal crashes were more likely to be sitting in the front, riding in a light truck (as opposed to a car), riding in an older vehicle, and riding in a vehicle where the driver was determined to be at fault. Given these differences, one should hesitate before interpreting estimates based on the FARS as applicable to all crash types. For a detailed description of the Washington State DOT data, see Anderson et al. (2017).

${ }^{15}$ Based on the definition of "light trucks" from the FARS, this category includes vehicles such as SUVs, utility station wagons, vans, compact pickup trucks, and standard pickup trucks. Roughly 90 percent of children 2 to 9 years of age in the data were occupants of a passenger car or a light truck.
} 
those for children in child safety seats or standard seat belts. Child safety seats and seat belts appear similar in terms of raw fatality rates.

It is unlikely, however, that these raw fatality rates reflect causal estimates. Factors such as vehicle type, crash severity, and the driver's own risk preference could be simultaneously correlated with the choice of child restraint and the risk of being involved in a fatal accident. Child restraint device use may also influence whether a crash is included in the data set. In this regard, there is sample selection bias that is unaccounted for when focusing on simple means (Levitt and Porter 2001).

In an effort to control for factors simultaneously correlated with child restraint choice and traffic fatality risk, we estimate the following equation:

$$
\begin{aligned}
& \text { Fatality }_{i v c t}=\beta_{0}+\beta_{1} \text { Booster Seat }_{i v c t}+\beta_{2} \text { Child Seat }_{i v c t}+\beta_{3} \text { Seat Belt Only } \text { ivct } \\
& +\boldsymbol{X} \mathbf{1}_{\text {ivct }} \boldsymbol{\beta}_{\mathbf{5}}+\boldsymbol{X} \mathbf{2}_{v c t} \boldsymbol{\beta}_{\mathbf{6}}+\boldsymbol{X} \boldsymbol{3}_{c t} \boldsymbol{\beta}_{7}+\varepsilon_{\text {ivct }},
\end{aligned}
$$

where Fatality $_{\text {ivct }}$ is equal to one if child $i$ in vehicle $v, \operatorname{crash} c$, and year $t$ died, and is equal to zero otherwise. ${ }^{16}$ The variables Booster Seat ${ }_{i v c t}$, Child Seat ivct$_{\text {, }}$ and Seat Belt Only ivct $_{\text {are mutually }}$ exclusive indicators for the type of restraint device used. ${ }^{17}$ The omitted category is no restraint

\footnotetext{
${ }^{16}$ In alternative specifications, we experimented with replacing Fatality with an indicator for whether the child was taken to a medical facility by some form of EMS transport. The results from this exercise suggested that all three forms of restraint are equally effective.

${ }^{17}$ A departure of our estimating equation from that of Levitt's (2008) is that our variable Seat Belt Only covers both lap-and-shoulder and lap-only seat belts. Levitt (2008) included separate indicators for each type of seat belt. For his sample, a nearly equal proportion of children were restrained in lap-and-shoulder and lap-only belts. In our sample, children in lap-and-shoulder belts outnumber those in lap-only belts nearly 8 to 1 . This reflects the fact that lap-only belts are being phased out of existence. Since 1989, the NHTSA has required that all rear outboard seats in new passenger vehicles be equipped with lap-and-shoulder belts. In 2004, the NHTSA ruled that all rear center seats in new passenger vehicles must be equipped with lap-and-shoulder belts by 2008 (NHTSA 2005). Our results change little if we drop children restrained in lap-only belts from the sample.
} 
use. The vector $\boldsymbol{X} \boldsymbol{1}_{\text {ivct }}$ includes individual-level controls for seat position (front, back left, back middle, back right, back 'other'), gender, and age. It is important to control for seat position because children in booster seats and child safety seats are more likely to ride in the back than children in adult seat belts or children riding unrestrained. ${ }^{18}$ Research suggests that sitting in a back seat may reduce the risk of death, especially for children (Smith and Cummings 2006).

The vector $\boldsymbol{X} \boldsymbol{2}_{v c t}$ includes vehicle-level controls for vehicle type, model year, vehicle weight, point of impact, seat belt status of the driver, the driver's injury severity, and the driver's accident and violation history. Seat belt status of the driver and the driver's accident and violation history serve as proxies for unobserved driver tastes and preferences. For instance, safer drivers may be more likely to appropriately restrain child passengers. In interviews with nearly 1,500 parents of children 4 to 9 years of age, Bruce et al. (2011) found that the strongest determinants of the intent to use a booster seat were parental attitudes and beliefs. The severity of the driver's injury proxies for the severity of the accident. ${ }^{19}$

The vector $\boldsymbol{X} \boldsymbol{3}_{c t}$ includes crash-level controls for the number of persons and cars involved, the speed limit, road type, time of day, whether the crash happened on a weekend, year of the crash, and the state in which the crash occurred. ${ }^{20}$ Following Levitt (2008), all regressions are estimated as linear probability models and standard errors are clustered at the vehicle level. This

\footnotetext{
${ }^{18}$ Roughly 96 percent of children in booster seats or child safety seats in our sample were in a back seat. On the other hand, approximately 81 percent of children in adult seat belts or riding unrestrained were in a back seat.

${ }^{19}$ By conditioning on proxies for driver safety awareness and crash severity, we can rule out Peltzman and adverse selection effects. A Peltzman (1975) effect, where restraint use promotes aggressive driving and causes more severe crashes, would lead to estimates that understate the true value of restraint use. Alternatively, if cautious drivers are more likely to use restraint devices, then estimates of their effectiveness would be overstated.

${ }^{20}$ Because the FARS data only include fatal accidents, the more people who are involved in the accident, the more likely the accident is included in the data set (Levitt 2008).
} 
clustering takes into account the fact that there are sometimes multiple child passengers in the same vehicle. ${ }^{21}$

Table 2 illustrates definitions and descriptive statistics for the control variables used in the analysis. Means are provided for the full sample and for samples restricted by restraint type. Roughly 75 percent of the sample rode restrained by some type of device. This is significantly higher than the 44 percent who rode restrained in Levitt's (2008) sample, reflecting an increasing trend in restraint device use. Unrestrained children were more likely to have ridden in an older vehicle and with a driver who was also unbelted, suffered a serious injury, and had been charged with a driving violation in the past 3 years. Unrestrained children were also more likely to have been in a one-car or early morning accident.

Because the FARS data include only crashes where at least one person died and restraint devices likely influence the probability of death, there is a sample selection problem. Failing to account for this problem will result in estimates that understate the true value of effective restraint devices. To address the sample selection issue, we limit the sample to two-car crashes where someone in the other vehicle died (Levitt and Porter 2001). ${ }^{22}$ Holding other factors constant, the assumption is that restraint choice in one vehicle is independent of the fatality outcomes in the other vehicle. This sample selection correction breaks the link between restraint

\footnotetext{
${ }^{21}$ Following Doyle and Levitt (2010), we also control for interactions between driver seat belt status and driver injuries. To retrain sample size, we include dummy variables to indicate missing information on seat position, gender, point of contact, driver characteristics, vehicle characteristics, and crash characteristics. We also experimented with controlling for vehicle fixed effects. However, because we observe little within-vehicle variation in restraint use, the restraint device estimates became imprecise. Despite the imprecision, the conclusions were similar to those reached below. Booster seats appeared no more effective at decreasing the risk of fatality than child safety seats or seat belts alone and, in some cases, they were the least effective form of restraint. Finally, we considered clustering the standard errors at the accident level. Inference based on this level of clustering was similar to that based on clustering at the vehicle level.

${ }^{22}$ See Levitt and Porter (2001) for a formal treatment of the sample selection problem.
} 
choice and inclusion in the FARS data set. While restraint use in one car should not directly influence the likelihood of fatality in the other car, threats to causal identification could come through indirect channels. Consider the example provided by Levitt and Porter (2001). Restraint use could be correlated with driving safer cars, and safer cars may be more likely to get into accidents with other safer cars. In this particular case, controlling for vehicle type is required for a causal interpretation. After controlling for the extensive set of individual-, vehicle-, and crashlevel characteristics listed in Table 2, and the characteristics of the other driver (seat belt use, accident history, and prior driving violations) and car (weight and type) involved in the crash, we assume that the choice of restraint in one vehicle is independent of the unobserved characteristics in the other vehicle that may affect the likelihood of fatality.

Finally, because the subset of crashes based on the sample selection correction are generally less severe than the average crash in the FARS data, it is not clear whether the estimates based on the corrected sample generalize to all crashes.

\section{RESULTS}

Table 3 presents the main results of the paper. Panel I provides estimates from specifications without the sample selection correction. For each age group, estimates are shown from models with and without the covariates listed in Table $2 .{ }^{23}$ Across all ages and all types of restraint devices, estimates are negative and statistically significant at the one percent level. For children 2 to 9 years of age and controlling for the covariates listed in Table 2, booster seats reduce the probability of fatality by 11.4 percentage points. This equates to an approximate 37

\footnotetext{
${ }^{23}$ Note that the models that control for the covariates listed in Table 2 also control for state fixed effects, year fixed effects, and interactions between driver injuries and driver seat belt status. The models based on the sample selection correction also control for characteristics of the other vehicle (weight and type) and the other driver (seat belt status, accident history, and prior driving violation charges) involved in the crash.
} 
percent decrease relative to the mean fatality rate for unrestrained children. While this represents a sizable reduction, child safety seats and standard seat belts appear more effective. In fact, across all samples, we reject the null hypotheses that the coefficient estimate on Booster Seat is equal to the coefficient estimate on Child Seat or the coefficient estimate on Seat Belt Only. For the full sample, child safety seats appear slightly more effective than standard seat belts. However, we cannot reject the null that the coefficient estimate on Child Seat is equal to the coefficient estimate on Seat Belt Only for children 2 to 5 or 6 to 9 years of age.

Panel II illustrates results from our preferred specifications that are based on the sample selection correction. In general, the sizes of the coefficient estimates are smaller than those in Panel I. This reflects the fact that these crashes are typically less severe than those based on the entire sample. For children 2 to 9 years of age and controlling for the covariates listed in Table 2 , riding in a booster seat is associated with a decrease in the probability of fatality by 6.8 percentage points. This represents a 58 percent decrease relative to the mean fatality rate for unrestrained children. As expected, the magnitude of the effect is larger in the sample corrected for selection. In this case, we fail to reject the null hypotheses that the coefficient estimate on Booster Seat is equal to the coefficient estimate on Child Seat or the coefficient estimate on Seat Belt Only.

For children 2 to 5 years of age, the coefficient estimates on Child Seat and Seat Belt Only are over 50 and 70 percent larger in magnitude, respectively, than the coefficient estimate on Booster Seat when controlling for the covariates listed in Table 2. This is consistent with the notion that premature graduation from a child safety seat to a booster seat can be particularly dangerous (Zipp 2013; Pickrell and Choi 2014). The coefficient estimate on Booster Seat, however, is measured imprecisely. In fact, we cannot reject the hypotheses that booster seats and 
child safety seats or booster seats and seat belts are equally effective at conventional levels of statistical significance. Lastly, and consistent with Levitt's (2008) findings, child safety seats seemingly afford the same level of protection against fatal injuries as do standard seat belts for children ages 2 through 5. For older children, the estimates in Table 3 suggest that all three forms of restraint are equally effective. ${ }^{24,25}$

In Table 4, we allow for measurement error in the type of child restraint device reported by replacing the variables Booster Seat and Child Seat with an indicator that is equal to one if the child was coded as restrained by either type of device. It is possible that reporting officers at the scene of the crash do not always correctly record the type of restraint device used by child passengers. Furthermore, it is not obvious whether this form of measurement error would be uncorrelated with the likelihood of fatality. Defining the child restraint device variable broadly also allows us to include observations where the type of child restraint device was coded as

\footnotetext{
${ }^{24}$ In Appendix Table 1, we consider finer breakdowns by age. Specifically, we estimate our models separately for children in the following age groups: 2-3, 4-6, and 7-9. In general, the interpretation of our findings remains similar. For the sample based on the selection correction and across all three age groups, we fail to reject the hypotheses that booster seats and child safety seats or booster seats and seat belts are equally effective at conventional levels of statistical significance. In results not reported here, but available upon request, we also considered 2-year and single-year age groupings. While these estimates were generally less precise, the overall interpretation of our findings remained qualitatively similar.

${ }^{25}$ In Appendix Table 2, we consider more inclusive sample selection corrections. Including additional observations in our corrected samples, comes with two advantages. First, it increases precision. Second, our samples become more representative of fatal accidents in the United States. In panel I, rather than focusing only on two-car crashes where someone in the other car died, we also include observations where the driver of child $i$ 's vehicle died. In panel II, we instead include observations where the driver of the other vehicle was likely to have been at fault. This latter criterion is specifically designed to address the fact that Levitt and Porter's (2001) correction may actually induce a source of selection if "...drivers of vehicles who cause fatalities in other vehicles are also less likely to restrain young children correctly, which is a plausible scenario" (Elliot et al. 2009, pg. 442). We define the other driver to have likely been at fault if they were charged with one of the following violations: reckless/careless driving, hit-and-run, driving while impaired, speed-related offense, or breaking a "rule of the road" (e.g., traffic sign or signaling violations). In panels I and II, booster seats appear to be the least effective form of restraint for children ages 2 through 5, but equally effective relative to child safety seats and seat belts alone for children ages 6 through 9. Of course, the drawback to either of these approaches is that they require stronger assumptions to break the link between child restraint choice and inclusion in the data set.
} 
"unknown." Across all age groups, we find little difference between the effectiveness of broadly-defined child restraint devices and seat belts alone. ${ }^{26}$

Table 5 presents results for various subsamples of the data for children 2 to 9 years of age. Specifically, we consider children riding in luxury versus non-luxury vehicles ${ }^{27}$, cars versus light trucks, newer versus older vehicles ${ }^{28}$, and vehicles by the initial point of impact. ${ }^{29}$ In all but two cases, booster seats appear statistically similar to the alternative forms of restraint. In luxury vehicles, booster seats appear marginally more effective at decreasing the risk of fatality than child safety seats; in non-frontal impacts, booster seats appear less effective at decreasing the risk of fatality than seat belts alone. One should note, however, that in some of these subsamples the cell sizes become quite small, making it difficult to precisely estimate the effects of boosters or child safety seats. ${ }^{30}$

Finally, the results presented above reflect how booster seats are used in practice. While Greenwell (2015) estimated improper use to be substantially lower for booster seats relative to

\footnotetext{
${ }^{26}$ If we restrict our sample to 2- to 6-year-olds, this specification most closely mirrors that considered in Levitt (2008). Like Levitt (2008), we fail to reject the null hypothesis that the coefficient estimate on a broadly-defined child restraint variable is equal to the coefficient estimate on a seat belt indicator.

${ }^{27}$ For luxury versus non-luxury vehicle make, we followed the Kelley Blue Book categorization (www.kbb.com).

${ }^{28}$ The mean age of vehicles in the sample was approximately 10 years. We defined "newer" vehicles as those that were below this cutoff and "older" vehicles as those that were at or above this cutoff.

${ }^{29}$ Recently, there have been calls by the U.S. government to test the effectiveness of child restraint devices in sideimpact crashes (Lucas 2014). Unfortunately, our cell sizes were simply too small to credibly estimate restraintdevice effects for side crashes only.

${ }^{30} \mathrm{We}$ also experimented with interacting each of our restraint-type variables with a state booster seat law indicator. If, for instance, parents living in states with a booster seat law are more diligent when installing their child's booster, we may observe heterogeneous restraint device effects across states. In general, we found no evidence to support the existence of these interactive effects. The results described here are available from the authors upon request. For an analysis of child safety seat laws for the period 1975-2011, see Jones and Ziebarth (2017).
} 
child safety seats, the misuse of booster seats would cause our estimates to understate their true value. $^{31}$

\section{CONCLUSION}

In the past 20 years, booster seats have gone from almost nonexistent to one of the more popular choices of child car restraint (Decina and Knoebel 1997; Pickrell and Choi 2014).

Despite this trend and an intense public interest in child traffic safety, credible estimates on the life-saving effects of booster seats remain absent from the literature.

To examine the relationship between booster seat use and the risk of fatality, we draw upon data from the Fatality Analysis Reporting System for the period 2008-2016 and employ the sample selection correction proposed by Levitt and Porter (2001). Until a recent innovation in the FARS, researchers were unable to examine booster seat effectiveness. In 2008, the FARS began distinguishing between booster seats and child safety seats in its crash reports.

For the younger children in our sample (2- to 5-year-olds) and in our preferred specifications, we find some evidence to suggest that booster seats are the inferior form of restraint. Child safety seats and seat belts alone are associated with over 50 and 70 percent larger reductions in the risk of fatality, respectively, than are booster seats. These results are consistent with the notion that putting a child in a booster seat too soon, may be especially unsafe (Zipp 2013; Pickrell and Choi 2014). However, because the booster seat effect we observe is measured with imprecision, we cannot formally reject the hypotheses that booster seats and child safety

\footnotetext{
${ }^{31}$ Since 2008, the FARS has recorded whether a child safety or booster seat was used improperly. When we drop these observations from our sample, our results change little. However, only about 1 percent of the children we observe were coded as riding in an improperly used child restraint device. Given that Greenwell (2015) estimated boosters are used improperly in nearly 18 percent of cases, underreporting of misuse is likely present in our data.
} 
seats or booster seats and seat belts are equally effective at conventional levels of statistical significance. For the older children in our sample (6- to 9-year-olds), our results suggest that booster seats, child safety seats, and seat belts alone are equally effective at decreasing the probability of fatality. ${ }^{32}$

From a policy perspective, our results are vital as federal, state, and local governments must decide on how to best allocate their budgets earmarked for traffic safety. Funding decisions made by the National Highway Traffic Safety Administration (NHTSA) even depend on information from the FARS (NHTSA 2013). ${ }^{33}$ The NHTSA promotes public messaging campaigns intended to increase parental knowledge of booster seat safety and has outlined booster-seat enforcement strategies that include law enforcement training and judicial outreach (Decina et al. 2008). ${ }^{34}$ It is important that policy decisions such as these and booster seat recommendations made by the American Academy of Pediatrics (AAP) be based on reliable estimates of booster seat effectiveness (Durbin 2011). Our findings also provide important information for state legislatures contemplating specific age ranges for their booster seat requirements.

\footnotetext{
${ }^{32}$ In a previous version of this paper, based on a shorter panel of data (2008-2014), booster seats appeared to be the superior form of restraint for children ages 6 through 8 (Anderson and Sandholt 2016).

33 The NHTSA's fiscal year 2016 budget request totaled $\$ 908$ million and included $\$ 179$ million for vehicle safety, $\$ 152$ million for behavioral safety, and $\$ 577$ million for state grants and high visibility enforcement support (NHTSA 2016).

${ }^{34}$ The NHTSA recommends that law enforcement officers complete a child passenger safety certification course, with a component in the curriculum on booster seats. The NHTSA also promotes educating local magistrates and other judiciary members to enhance their understanding of booster seat laws (Decina et al. 2008).
} 


\section{REFERENCES}

Abouk, Rahi and Scott Adams. 2013. "Texting Bans and Fatal Accidents on Roadways: Do They Work? Or Do Drivers Just React to Announcements of Bans?" American Economic Journal: Applied Economics 5: 179-199.

Adams, Scott, McKinley Blackburn, and Chad Cotti. 2012. "Minimum Wages and AlcoholRelated Traffic Fatalities among Teens." Review of Economics and Statistics 94: 828840 .

Adams, Scott and Chad Cotti. 2008. "Drunk Driving After the Passage of Smoking Bans in Bars." Journal of Public Economics 92: 1288-1305.

Anderson, D. Mark, Lindsay Carlson, and Daniel Rees. 2017. "Booster Seat Effectiveness Among Older Children: Evidence from Washington State." American Journal of Preventative Medicine 53: 210-215.

Anderson, D. Mark, Benjamin Hansen, and Daniel Rees. 2013. "Medical Marijuana Laws, Traffic Fatalities, and Alcohol Consumption." Journal of Law and Economics 56: 333369.

Anderson, D. Mark and Sina Sandholt. 2016. "Booster Seats and Traffic Fatalities among Children.” IZA Discussion Paper No. 10071.

Arbogast, Kristy, Jessica Jermakian, Michael Kallan, and Dennis Durbin. 2009. "Effectiveness of Belt Positioning Booster Seats: An Updated Assessment.” Pediatrics 124: 1281-1286.

Bae, Jin Yung, Evan Anderson, Diana Silver, and James Macinko. 2014. "Child Passenger Safety Laws in the United States, 1978-2010: Policy Diffusion in the Absence of Strong Federal Intervention." Social Science and Medicine 100: 30-37.

Bruce, Beth, Anne Snowdon, Charles Cunningham, Carolyn Cramm, Krista Whittle, Heather Correale, Melanie Barwick, Caroline Piotrowski, Lynne Warda, and Jessie Harold. 2011. "Predicting Parents' Use of Booster Seats." Injury Prevention 17: 313-318.

Carpenter, Christopher and Carlos Dobkin. 2009. "The Effect of Alcohol Consumption on Mortality: Regression Discontinuity Evidence from the Minimum Drinking Age." American Economic Journal: Applied Economics 1: 164-182.

Carpenter, Christopher and Mark Stehr. 2008. "The Effects of Mandatory Seatbelt Laws on Seatbelt Use, Motor Vehicle Fatalities, and Crash-Related Injuries among Youths." Journal of Health Economics 27: 642-662.

Centers for Disease Control and Prevention. 2015. "Ten Leading Causes of Death and Injury." Available at: http://www.cdc.gov/injury/wisqars/leadingcauses.html. 
Cohen, Alma and Rajeev Dehejia. 2004. "The Effect of Automobile Insurance and Accident Liability Laws on Traffic Fatalities." Journal of Law and Economics 47: 357-393.

Cohen, Alma and Liran Einav. 2003. "The Effects of Mandatory Seat Belt Laws on Driving Behavior and Traffic Fatalities." Review of Economics and Statistics 85: 828-843.

Decina, Lawrence and Kathleen Knoebel. 1997. "Child Safety Seat Misuse Patterns in Four States." Accident Analysis and Prevention 29: 125-132.

Decina, Lawrence, Kathy Lococo, Warren Ashburn, William Hall, and Janelle Rose. 2008. "Identifying Strategies to Improve the Effectiveness of Booster Seat Laws." NHTSA Report No DOT HS 810969.

Dee, Thomas. 2001. "Does Setting Limits Save Lives? The Case of 0.08 BAC Laws." Journal of Policy Analysis and Management 20: 113-130.

Dee, Thomas. 2009. "Motorcycle Helmets and Traffic Safety." Journal of Health Economics 28: 398-412.

Dee, Thomas, David Grabowski, and Michael Morrisey. 2005. "Graduated Driver Licensing and Teen Traffic Fatalities." Journal of Health Economics 24: 571-589.

Dickert-Conlin, Stacy, Todd Elder, and Brian Moore. 2011. "Donorcycles: Motorcycle Helmet Laws and the Supply of Organ Donors." Journal of Law and Economics 54: 907-935.

Doyle, Joseph and Steven Levitt. 2010. "Evaluating the Effectiveness of Child Safety Seats and Seat Belts in Protecting Children from Injury." Economic Inquiry 48: 521-536.

Durbin, Dennis. 2011. “Technical Report - Child Passenger Safety." Pediatrics 127: e1050e1066.

Durbin, Dennis, Michael Elliot, and Flaura Winston. 2003. "Belt-Positioning Booster Seats and Reduction in Risk of Injury Among Children in Vehicle Crashes." Journal of the American Medical Association 289: 2835-2840.

Elliott, Michael, Dennis Durbin, and Flaura Winston. 2009. "A Propensity Score Approach to Estimating Child Restraint Effectiveness in Preventing Mortality." Statistics and Its Interface 2: 437-447.

Elliott, Michael, Michael Kallan, Dennis Durbin, and Flaura Winston. 2006. "Effectiveness of Child Safety Seats vs Seat Belts in Reducing Risk for Death in Children in Passenger Vehicle Crashes." Archives of Pediatrics and Adolescent Medicine 160: 617-621.

Governors Highway Safety Association. 2016. "Child Passenger Safety Laws.” Available at: http://www.ghsa.org/html/stateinfo/laws/childsafety_laws.html. 
Grant, Darren. 2010. "Dead on Arrival: Zero Tolerance Laws Don't Work." Economic Inquiry 48: $756-770$.

Greenwell, Nathan. 2015. "Results of the National Child Restraint Use Special Study." NHTSA Report No DOT HS 812 142. Available at: https://crashstats.nhtsa.dot.gov/Api/Public/ViewPublication/812142.

Hagan, Joseph, Judith Shaw, and Paula Duncan. 2008. Bright Futures: Guidelines for Health Supervision of Infants, Children, and Adolescents, Third Edition. Elk Grove Village, IL: American Academy of Pediatrics.

Hertz, E. 1996. "Revised Estimates of Child Restraint Effectiveness.” NHTSA Research Note.

Jacobson, Susan. 2015. "Florida Strengthens Child Booster-Seat Law.” Orlando Sentinel. Available at:

http://www.orlandosentinel.com/news/os-booster-seats-new-florida-law-20150126story.html.

Jones, Lauren and Nicolas Ziebarth. 2016. "Successful Scientific Replication and Extension of Levitt (2008): Child Seats are Still No Safer than Seat Belts.” Journal of Applied Econometrics 31: 920-928.

Jones, Lauren and Nicolas Ziebarth. 2017. "U.S. Child Safety Seat Laws: Are they Effective, and Who Complies?” Journal of Policy Analysis and Management 36: 584-607.

Kahane, Charles. 1986. "An Evaluation of Child Passenger Safety: The Effectiveness and Benefits of Safety Seats.” NHTSA Report No DOT HS 806890.

Levitt, Steven. 2008. "Evidence that Seat Belts are as Effective as Child Safety Seats in Preventing Death for Children Aged Two and Up." Review of Economics and Statistics 90: 158-163.

Levitt, Steven and Jack Porter. 2001. "Sample Selection in the Estimation of Air Bag and Seat Belt Effectiveness." Review of Economics and Statistics 83: 603-615.

Lucas, Mary Grace. 2014. "U.S. Proposes New Crash Test for Car Seats.” CNN. Available at: http://www.cnn.com/2014/01/22/us/car-seats-crash-tests/index.html.

Ma, Xiaoguang, Russell Griffin, Gerald McGwin, David Allison, Steven Heymsfield, Wei He, and Shankuan Zhu. "Effectiveness of Booster Seats Compared with No Restraint or Seat Belt Alone for Crash Injury Prevention." Academic Emergency Medicine 20: 880-887.

Merrell, David, Marc Poitras, and Daniel Sutter. 1999. "The Effectiveness of Vehicle Safety Inspections: An Analysis Using Panel Data." Southern Economic Journal 65: 571-583. 
Morrisey, Michael and David Grabowski. 2005. "State Motor Vehicle Laws and Older Drivers." Health Economics 14: 407-419.

NHTSA. 2005. "Improving the Safety of Older-Child Passengers." Available at: http://icsw.nhtsa.gov/people/injury/childps/boosterseatprogress/.

NHTSA. 2013. "Fiscal Year 2013 Budget Overview." Available at: http://www.nhtsa.gov/Laws+\&+Regulations/NHTSA+Budget+Information.

NHTSA. 2016. "Fiscal Year 2016 Budget Overview." Available at: http://www.nhtsa.gov/Laws+\&+Regulations/NHTSA+Budget+Information.

O'Donnell, Jayne. 2011. "Car-Safety Group: Half of Child Booster Seats Pose Risks." USA Today. Available at: http://usatoday30.usatoday.com/money/autos/story/2011-10-13/boosterseats/50747988/1.

Partyka, Susan. 1988. "Lives Saved by Child Restraints from 1982 through 1987." NHTSA Report No DOT HS 807371.

Pediatric Center. 2005. "Boosters Are For Big Kids." Available at: http://www.thepediatriccenter.net/docs/beuf/SharedAssets/Booster.pdf.

Peltzman, Sam. 1975. "The Effects of Automobile Safety Regulation." Journal of Political Economy 83: 677-726.

Peterson, Steven, George Hoffer, and Edward Millner. 1995. "Are Drivers of Air-Bag-Equipped Cars More Aggressive? A Test of the Offsetting Behavior Hypothesis." Journal of Law and Economics 38: 251-263.

Pickrell, Timothy and Eun-Ha Choi. 2014. "The 2013 National Survey of the Use of Booster Seats.” NHTSA Report No DOT HS 812037.

Reed, Matthew, Sheila Ebert-Hamilton, Kathleen Klinich, Miriam Manary, and Jonathan Rupp. 2013. "Effects of Vehicle Seat and Belt Geometry on Belt Fit for Children with and without Belt Positioning Booster Seats." Accident Analysis and Prevention 50: 512-522.

Rice, Thomas and Craig Anderson. 2009. "The Effectiveness of Child Restraint Systems for Children Aged 3 Years or Younger during Motor Vehicle Collisions: 1996 to 2005." American Journal of Public Health 99: 252-257.

Rice, Thomas, Craig Anderson, and A. Lee. 2009. "The Association between Booster Seat Use and Risk of Death among Motor Vehicle Occupants Aged 4-8: A Matched Cohort Study." Injury Prevention 15: 379-383.

Sabia, Joseph J., M. Melinda Pitts, and Laura Argys. 2014. "Do Minimum Wages Really 
Increase Youth Drinking and Drunk Driving?" Federal Reserve Bank of Atlanta Working Paper 2014-20.

Sass, Tim and J. Paul Leigh. 1991. "The Market for Safety Regulation and the Effect of Regulation on Fatalities: The Case of Motorcycle Helmet Laws." Review of Economics and Statistics 73: 167-172.

Sass, Tim and Paul Zimmerman. 2000. "Motorcycle Helmet Laws and Motorcyclist Fatalities." Journal of Regulatory Economics 18: 195-215.

Sen, Anindya. 2001. "An Empirical Test of the Offset Hypothesis." Journal of Law and Economics 44: 481-510.

Sen, Anindya and Brent Mizzen. 2007. "Estimating the Impact of Seat Belt Use on Traffic Fatalities: Empirical Evidence from Canada." Canadian Public Policy 33: 315-335.

Smith, Kathleen and Peter Cummings. 2006. "Passenger Seating Position and the Risk of Passenger Death in Traffic Crashes: A Matched Cohort Study." Injury Prevention 12: 8386.

Zipp, Michele. 2013. "Putting Your Child in a Booster Seat Too Soon Could Have Tragic Consequences." Cafemom. Available at: http://thestir.cafemom.com/toddlers_preschoolers/149737/putting_your_child_in_a. 
Table 1. Descriptive Statistics on Fatal Injuries by Restraint Type

\begin{tabular}{cccccc}
\hline & Full sample & $\begin{array}{c}\text { No Restraint } \\
=1\end{array}$ & $\begin{array}{c}\text { Booster Seat } \\
=1\end{array}$ & $\begin{array}{c}\text { Child Seat } \\
=1\end{array}$ & $\begin{array}{c}\text { Seat Belt Only } \\
=1\end{array}$ \\
\hline $\begin{array}{c}\text { Ages 2-9 } \\
\text { Fatality }\end{array}$ & .162 & .305 & .188 & .103 & .105 \\
N & $(.369)$ & $(.461)$ & $(.391)$ & $(.304)$ & $(.306)$ \\
& 17,186 & 4,282 & 1,563 & 2,697 & 8,644 \\
Ages 2-5 & & & & \\
Fatality & .179 & .320 & .204 & .105 & .119 \\
N & $(.383)$ & $(.467)$ & $(.403)$ & $(.307)$ & $(.324)$ \\
& 7,404 & 1,986 & 921 & 2,443 & 2,054 \\
Ages 6-9 & & & & & \\
Fatality & .149 & .293 & .165 & .079 & .101 \\
N & $(.356)$ & $(.455)$ & $(.372)$ & $(.270)$ & $(.301)$ \\
\end{tabular}

Notes: Fatality is equal to one if the child died in the accident, and is equal to zero otherwise. Each cell represents the percentage of children who were fatally injured. Means (with SDs in parentheses) are based on unweighted data from the Fatality Analysis Reporting System (2008-2016). 
Table 2. Descriptive Statistics on Independent Variables by Restraint Type

\begin{tabular}{|c|c|c|c|c|c|c|}
\hline & $\begin{array}{c}\text { Full } \\
\text { sample }\end{array}$ & $\begin{array}{c}\text { No } \\
\text { Restraint } \\
=1\end{array}$ & $\begin{array}{l}\text { Booster } \\
\text { Seat }=1\end{array}$ & $\begin{array}{c}\text { Child } \\
\text { Seat }=1\end{array}$ & $\begin{array}{l}\text { Seat Belt } \\
\text { Only }=1\end{array}$ & Description \\
\hline \multicolumn{7}{|c|}{ Individual-level characteristics } \\
\hline \multicolumn{7}{|c|}{ Restraint type } \\
\hline No Restraint & $\begin{array}{l}.249 \\
(.433)\end{array}$ & 1.00 & $\ldots$ & $\ldots$ & $\cdots$ & $=1$ if child was unrestrained, $=0$ otherwise \\
\hline Booster Seat & $\begin{array}{l}.091 \\
(.288)\end{array}$ & $\ldots$ & 1.00 & $\ldots$ & $\ldots$ & $=1$ if child was in a booster seat, $=0$ otherwise \\
\hline Child Seat & $\begin{array}{c}.157 \\
(.364)\end{array}$ & $\ldots$ & $\ldots$ & 1.00 & $\cdots$ & $=1$ if child was in a child seat, $=0$ otherwise \\
\hline Seat Belt Only & $\begin{array}{l}.503 \\
(.500)\end{array}$ & $\ldots$ & $\ldots$ & $\ldots$ & 1.00 & $=1$ if child was in a seat belt only, $=0$ otherwise \\
\hline \multicolumn{7}{|l|}{ Child seat position } \\
\hline Front & $\begin{array}{l}.127 \\
(.333)\end{array}$ & $\begin{array}{l}.137 \\
(.343)\end{array}$ & $\begin{array}{l}.050 \\
(.218)\end{array}$ & $\begin{array}{c}.032 \\
(.177)\end{array}$ & $\begin{array}{l}.166 \\
(.372)\end{array}$ & $\begin{array}{l}=1 \text { if child was sitting in the front of the vehicle, } \\
=0 \text { otherwise }\end{array}$ \\
\hline Back Left & $\begin{array}{l}.309 \\
(.462)\end{array}$ & $\begin{array}{l}.227 \\
(.419)\end{array}$ & $\begin{array}{l}.386 \\
(.487)\end{array}$ & $\begin{array}{l}.377 \\
(.485)\end{array}$ & $\begin{array}{l}.313 \\
(.464)\end{array}$ & $\begin{array}{l}=1 \text { if child was sitting in the back left of the } \\
\text { vehicle }=0 \text { otherwise }\end{array}$ \\
\hline Back Middle & $\begin{array}{l}.164 \\
(.370)\end{array}$ & $\begin{array}{l}.210 \\
(.407)\end{array}$ & $\begin{array}{l}.116 \\
(.321)\end{array}$ & $\begin{array}{l}.166 \\
(.373)\end{array}$ & $\begin{array}{l}.149 \\
(.357)\end{array}$ & $\begin{array}{l}=1 \text { if child was sitting in the back middle of the } \\
\text { vehicle, }=0 \text { otherwise }\end{array}$ \\
\hline Back Right & $\begin{array}{l}.326 \\
(.469)\end{array}$ & $\begin{array}{l}.211 \\
(.408)\end{array}$ & $\begin{array}{l}.435 \\
(.496)\end{array}$ & $\begin{array}{l}.409 \\
(.492)\end{array}$ & $\begin{array}{l}.337 \\
(.473)\end{array}$ & $\begin{array}{l}=1 \text { if child was sitting in the back right of the } \\
\text { vehicle, }=0 \text { otherwise }\end{array}$ \\
\hline Back Other & $\begin{array}{l}.045 \\
(.208)\end{array}$ & $\begin{array}{l}.130 \\
(.336)\end{array}$ & $\begin{array}{l}.007 \\
(.084)\end{array}$ & $\begin{array}{l}.009 \\
(.096)\end{array}$ & $\begin{array}{l}.021 \\
(.144)\end{array}$ & $\begin{array}{l}=1 \text { if child was sitting in an "other" position in } \\
\text { the back of the vehicle, }=0 \text { otherwise }\end{array}$ \\
\hline Male & $\begin{array}{l}.507 \\
(.500)\end{array}$ & $\begin{array}{l}.517 \\
(.500)\end{array}$ & $\begin{array}{l}.512 \\
(.500)\end{array}$ & $\begin{array}{l}.508 \\
(.500)\end{array}$ & $\begin{array}{l}.502 \\
(.500)\end{array}$ & $=1$ if male, $=0$ otherwise \\
\hline Age 2 & $\begin{array}{l}.093 \\
(.290)\end{array}$ & $\begin{array}{l}.093 \\
(.291)\end{array}$ & $\begin{array}{l}.054 \\
(.227)\end{array}$ & $\begin{array}{l}.329 \\
(.470)\end{array}$ & $\begin{array}{l}.026 \\
(.159)\end{array}$ & $=1$ if two years of age, $=0$ otherwise \\
\hline Age 3 & $\begin{array}{l}.103 \\
(.304)\end{array}$ & $\begin{array}{l}.117 \\
(.321)\end{array}$ & $\begin{array}{l}.111 \\
(.314)\end{array}$ & $\begin{array}{l}.273 \\
(.445)\end{array}$ & $\begin{array}{l}.042 \\
(.200)\end{array}$ & $=1$ if three years of age, $=0$ otherwise \\
\hline Age 4 & $\begin{array}{l}.115 \\
(.318)\end{array}$ & $\begin{array}{l}.124 \\
(.329)\end{array}$ & $\begin{array}{l}.196 \\
(.397)\end{array}$ & $\begin{array}{l}.197 \\
(.398)\end{array}$ & $\begin{array}{l}.070 \\
(.254)\end{array}$ & $=1$ if four years of age, $=0$ otherwise \\
\hline Age 5 & $\begin{array}{l}.121 \\
(.326)\end{array}$ & $\begin{array}{l}.131 \\
(.337)\end{array}$ & $\begin{array}{l}.228 \\
(.420)\end{array}$ & $\begin{array}{l}.108 \\
(.310)\end{array}$ & $\begin{array}{l}.100 \\
(.300)\end{array}$ & $=1$ if five years of age, $=0$ otherwise \\
\hline Age 6 & $\begin{array}{l}.129 \\
(.335)\end{array}$ & $\begin{array}{l}.127 \\
(.333)\end{array}$ & $\begin{array}{l}.191 \\
(.393)\end{array}$ & $\begin{array}{l}.056 \\
(.231)\end{array}$ & $\begin{array}{l}.141 \\
(.349)\end{array}$ & $=1$ if six years of age, $=0$ otherwise \\
\hline Age 7 & $\begin{array}{l}.137 \\
(.344)\end{array}$ & $\begin{array}{l}.140 \\
(.347)\end{array}$ & $\begin{array}{l}.137 \\
(.344)\end{array}$ & $\begin{array}{l}.027 \\
(.161)\end{array}$ & $\begin{array}{l}.170 \\
(.376)\end{array}$ & $=1$ if seven years of age, $=0$ otherwise \\
\hline Age 8 & $\begin{array}{l}.150 \\
(.357)\end{array}$ & $\begin{array}{l}.141 \\
(.348)\end{array}$ & $\begin{array}{l}.063 \\
(.244)\end{array}$ & $\begin{array}{l}.007 \\
(.084)\end{array}$ & $\begin{array}{l}.215 \\
(.411)\end{array}$ & $=1$ if eight years of age, $=0$ otherwise \\
\hline Age 9 & $\begin{array}{l}.153 \\
(.360)\end{array}$ & $\begin{array}{l}.129 \\
(.335)\end{array}$ & $\begin{array}{l}.020 \\
(.139)\end{array}$ & $\begin{array}{l}.004 \\
(.064)\end{array}$ & $\begin{array}{l}.236 \\
(.425)\end{array}$ & $=1$ if nine years of age, $=0$ otherwise \\
\hline Vehicle-level characteristic & & & & & & \\
\hline Car & $\begin{array}{l}.376 \\
(.484)\end{array}$ & $\begin{array}{l}.346 \\
(.476)\end{array}$ & $\begin{array}{c}.414 \\
(.493)\end{array}$ & $\begin{array}{l}.388 \\
(.487)\end{array}$ & $\begin{array}{l}.379 \\
(.485)\end{array}$ & $=1$ if vehicle was a car, $=0$ otherwise \\
\hline Light Truck & $\begin{array}{l}.624 \\
(.484)\end{array}$ & $\begin{array}{l}.654 \\
(.476)\end{array}$ & $\begin{array}{l}.586 \\
(.493)\end{array}$ & $\begin{array}{l}.612 \\
(.487)\end{array}$ & $\begin{array}{l}.621 \\
(.485)\end{array}$ & $=1$ if vehicle was a light truck, $=0$ otherwise \\
\hline Model Year $\leq 1990$ & $\begin{array}{l}.023 \\
(.149)\end{array}$ & $\begin{array}{c}.043 \\
(.203)\end{array}$ & $\begin{array}{l}.012 \\
(.110)\end{array}$ & $\begin{array}{l}.014 \\
(.116)\end{array}$ & $\begin{array}{c}.017 \\
(.130)\end{array}$ & $\begin{array}{l}=1 \text { if vehicle model year was pre } 1991,=0 \\
\text { otherwise }\end{array}$ \\
\hline $1990<$ Model Year $\leq 2000$ & $\begin{array}{l}.309 \\
(.462)\end{array}$ & $\begin{array}{l}.406 \\
(.491)\end{array}$ & $\begin{array}{l}.263 \\
(.440)\end{array}$ & $\begin{array}{c}.224 \\
(.417)\end{array}$ & $\begin{array}{l}.295 \\
(.456)\end{array}$ & $\begin{array}{l}=1 \text { if vehicle model year was between } 1991 \text { and } \\
2000,=0 \text { otherwise }\end{array}$ \\
\hline Model Year $>2000$ & $\begin{array}{l}.652 \\
(.476)\end{array}$ & $\begin{array}{c}.544 \\
(.498)\end{array}$ & $\begin{array}{l}.704 \\
(.457)\end{array}$ & $\begin{array}{c}.731 \\
(.443)\end{array}$ & $\begin{array}{l}.671 \\
(.470)\end{array}$ & $\begin{array}{l}=1 \text { if vehicle model year was post } 2000,=0 \\
\text { otherwise }\end{array}$ \\
\hline Vehicle Weight $(1,000 \mathrm{~s}$ lbs. $)$ & $\begin{array}{c}1.40 \\
(1.90)\end{array}$ & $\begin{array}{c}1.52 \\
(1.93)\end{array}$ & $\begin{array}{l}1.03 \\
(1.74)\end{array}$ & $\begin{array}{c}1.14 \\
(1.79)\end{array}$ & $\begin{array}{l}1.50 \\
(1.93)\end{array}$ & Vehicle weight in thousands of pounds \\
\hline
\end{tabular}




\begin{tabular}{|c|c|c|c|c|c|c|}
\hline \multicolumn{7}{|l|}{ Point of impact } \\
\hline Non-Collision & $\begin{array}{c}.103 \\
(.303)\end{array}$ & $\begin{array}{c}.229 \\
(.420)\end{array}$ & $\begin{array}{c}.056 \\
(.229)\end{array}$ & $\begin{array}{c}.055 \\
(.229)\end{array}$ & $\begin{array}{c}.063 \\
(.243)\end{array}$ & $\begin{array}{l}=1 \text { if initial point of contact was classified as } \\
\text { "non-collision", }=0 \text { otherwise }\end{array}$ \\
\hline Direct Front & $\begin{array}{c}.474 \\
(.499)\end{array}$ & $\begin{array}{l}.348 \\
(.476)\end{array}$ & $\begin{array}{l}.503 \\
(.500)\end{array}$ & $\begin{array}{l}.514 \\
(.500)\end{array}$ & $\begin{array}{l}.519 \\
(.500)\end{array}$ & $\begin{array}{l}=1 \text { if initial point of contact was at the direct front } \\
\text { of the vehicle, }=0 \text { otherwise }\end{array}$ \\
\hline Partial Front & $\begin{array}{l}.121 \\
(.326)\end{array}$ & $\begin{array}{l}.113 \\
(.317)\end{array}$ & $\begin{array}{l}.132 \\
(.338)\end{array}$ & $\begin{array}{l}.132 \\
(.339)\end{array}$ & $\begin{array}{l}.119 \\
(.323)\end{array}$ & $\begin{array}{l}=1 \text { if initial point of contact was at the partial } \\
\text { front of the vehicle },=0 \text { otherwise }\end{array}$ \\
\hline Direct Rear & $\begin{array}{l}.080 \\
(.272)\end{array}$ & $\begin{array}{l}.048 \\
(.214)\end{array}$ & $\begin{array}{l}.097 \\
(.296)\end{array}$ & $\begin{array}{l}.096 \\
(.295)\end{array}$ & $\begin{array}{l}.089 \\
(.284)\end{array}$ & $\begin{array}{l}=1 \text { if initial point of contact was at the direct rear } \\
\text { of the vehicle, }=0 \text { otherwise }\end{array}$ \\
\hline Partial Rear & $\begin{array}{l}.053 \\
(.224)\end{array}$ & $\begin{array}{c}.058 \\
(.234)\end{array}$ & $\begin{array}{c}.051 \\
(.220)\end{array}$ & $\begin{array}{l}.047 \\
(.213)\end{array}$ & $\begin{array}{l}.052 \\
(.222)\end{array}$ & $\begin{array}{l}=1 \text { if initial point of contact was at the partial rear } \\
\text { of the vehicle, }=0 \text { otherwise }\end{array}$ \\
\hline Right Side & $\begin{array}{l}.064 \\
(.245)\end{array}$ & $\begin{array}{l}.076 \\
(.265)\end{array}$ & $\begin{array}{c}.062 \\
(.241)\end{array}$ & $\begin{array}{l}.053 \\
(.225)\end{array}$ & $\begin{array}{l}.062 \\
(.241)\end{array}$ & $\begin{array}{l}=1 \text { if initial point of contact was at the right side } \\
\text { of the vehicle, }=0 \text { otherwise }\end{array}$ \\
\hline Left Side & $\begin{array}{l}.067 \\
(.250)\end{array}$ & $\begin{array}{l}.071 \\
(.257)\end{array}$ & $\begin{array}{l}.071 \\
(.257)\end{array}$ & $\begin{array}{l}.073 \\
(.260)\end{array}$ & $\begin{array}{l}.062 \\
(.241)\end{array}$ & $\begin{array}{l}=1 \text { if initial point of contact was at the left side of } \\
\text { the vehicle, }=0 \text { otherwise }\end{array}$ \\
\hline Other Contact Point & $\begin{array}{l}.020 \\
(.139)\end{array}$ & $\begin{array}{l}.023 \\
(.150)\end{array}$ & $\begin{array}{l}.012 \\
(.107)\end{array}$ & $\begin{array}{l}.019 \\
(.135)\end{array}$ & $\begin{array}{l}.019 \\
(.137)\end{array}$ & $\begin{array}{l}=1 \text { if initial point of contact was at an "other" } \\
\text { contact point, }=0 \text { otherwise }\end{array}$ \\
\hline Driver Unbelted & $\begin{array}{l}.195 \\
(.396)\end{array}$ & $\begin{array}{l}.446 \\
(.497)\end{array}$ & $\begin{array}{l}.118 \\
(.323)\end{array}$ & $\begin{array}{l}.114 \\
(.318)\end{array}$ & $\begin{array}{l}.110 \\
(.313)\end{array}$ & $=1$ if driver was unbelted, $=0$ otherwise \\
\hline Driver Uninjured & $\begin{array}{l}.267 \\
(.442)\end{array}$ & $\begin{array}{l}.117 \\
(.321)\end{array}$ & $\begin{array}{l}.232 \\
(.422)\end{array}$ & $\begin{array}{l}.310 \\
(.462)\end{array}$ & $\begin{array}{l}.334 \\
(.472)\end{array}$ & $=1$ if driver was uninjured, $=0$ otherwise \\
\hline Driver Minor Injury & $\begin{array}{l}.324 \\
(.468)\end{array}$ & $\begin{array}{l}.344 \\
(.475)\end{array}$ & $\begin{array}{l}.347 \\
(.476)\end{array}$ & $\begin{array}{l}.320 \\
(.467)\end{array}$ & $\begin{array}{l}.311 \\
(.463)\end{array}$ & $=1$ if driver suffered a minor injury, $=0$ otherwise \\
\hline Driver Major/Fatal Injury & $\begin{array}{l}.397 \\
(.489)\end{array}$ & $\begin{array}{l}.523 \\
(.500)\end{array}$ & $\begin{array}{l}.409 \\
(.492)\end{array}$ & $\begin{array}{l}.362 \\
(.481)\end{array}$ & $\begin{array}{l}.343 \\
(.475)\end{array}$ & $\begin{array}{l}=1 \text { if driver suffered a major injury or died, }=0 \\
\text { otherwise }\end{array}$ \\
\hline Driver Past Accident & $\begin{array}{l}.109 \\
(.311)\end{array}$ & $\begin{array}{l}.105 \\
(.306)\end{array}$ & $\begin{array}{l}.125 \\
(.331)\end{array}$ & $\begin{array}{l}.108 \\
(.311)\end{array}$ & $\begin{array}{l}.107 \\
(.309)\end{array}$ & $\begin{array}{l}=1 \text { if driver was in a previous accident in the past } \\
3 \text { years, }=0 \text { otherwise }\end{array}$ \\
\hline Driver Past Violation & $\begin{array}{l}.344 \\
(.475)\end{array}$ & $\begin{array}{l}.394 \\
(.489)\end{array}$ & $\begin{array}{l}.328 \\
(.469)\end{array}$ & $\begin{array}{l}.330 \\
(.470)\end{array}$ & $\begin{array}{l}.326 \\
(.469)\end{array}$ & $\begin{array}{l}=1 \text { if driver was charged with a driving violation } \\
\text { in the past } 3 \text { years, }=0 \text { otherwise }\end{array}$ \\
\hline \multicolumn{7}{|l|}{ Crash-level characteristics } \\
\hline Persons in Crash & $\begin{array}{l}5.95 \\
(4.04)\end{array}$ & $\begin{array}{c}6.12 \\
(3.08)\end{array}$ & $\begin{array}{l}5.53 \\
(2.79)\end{array}$ & $\begin{array}{c}5.72 \\
(5.35)\end{array}$ & $\begin{array}{l}6.00 \\
(4.17)\end{array}$ & Number of persons involved in the crash \\
\hline One-Car Crash & $\begin{array}{l}.342 \\
(.475)\end{array}$ & $\begin{array}{l}.532 \\
(.499)\end{array}$ & $\begin{array}{l}.260 \\
(.439)\end{array}$ & $\begin{array}{l}.254 \\
(.435)\end{array}$ & $\begin{array}{l}.291 \\
(.454)\end{array}$ & $=1$ if crash was a one-car crash, $=0$ otherwise \\
\hline Two-Car Crash & $\begin{array}{l}.485 \\
(.500)\end{array}$ & $\begin{array}{l}.390 \\
(.488)\end{array}$ & $\begin{array}{l}.536 \\
(.499)\end{array}$ & $\begin{array}{l}.534 \\
(.499)\end{array}$ & $\begin{array}{l}.509 \\
(.500)\end{array}$ & $=1$ if crash was a two-car crash, $=0$ otherwise \\
\hline Three-Plus-Car Crash & $\begin{array}{l}.172 \\
(.378)\end{array}$ & $\begin{array}{l}.078 \\
(.269)\end{array}$ & $\begin{array}{l}.205 \\
(.404)\end{array}$ & $\begin{array}{l}.212 \\
(.409)\end{array}$ & $\begin{array}{l}.200 \\
(.400)\end{array}$ & $\begin{array}{l}=1 \text { if crash was a three-plus-car crash, }=0 \\
\text { otherwise }\end{array}$ \\
\hline Speed Limit $<55$ MPH & $\begin{array}{l}.383 \\
(.486)\end{array}$ & $\begin{array}{l}.325 \\
(.468)\end{array}$ & $\begin{array}{l}.354 \\
(.478)\end{array}$ & $\begin{array}{l}.372 \\
(.483)\end{array}$ & $\begin{array}{l}.420 \\
(.494)\end{array}$ & $\begin{array}{l}=1 \text { if speed limit was less than } 55 \mathrm{mph},=0 \\
\text { otherwise }\end{array}$ \\
\hline Rural Road & $\begin{array}{l}.439 \\
(.496)\end{array}$ & $\begin{array}{l}.529 \\
(.499)\end{array}$ & $\begin{array}{l}.430 \\
(.495)\end{array}$ & $\begin{array}{l}.364 \\
(.481)\end{array}$ & $\begin{array}{l}.419 \\
(.493)\end{array}$ & $=1$ if crash was on a rural road, $=0$ otherwise \\
\hline Early Morning & $\begin{array}{l}.067 \\
(.249)\end{array}$ & $\begin{array}{l}.110 \\
(.313)\end{array}$ & $\begin{array}{l}.050 \\
(.218)\end{array}$ & $\begin{array}{l}.060 \\
(.238)\end{array}$ & $\begin{array}{l}.050 \\
(.219)\end{array}$ & $\begin{array}{l}=1 \text { if crash occurred during the early morning } \\
\text { hours }(1: 00 \text { a.m. to } 5: 59 \text { a.m. }),=0 \text { otherwise }\end{array}$ \\
\hline Daytime & $\begin{array}{l}.757 \\
(.429)\end{array}$ & $\begin{array}{l}.709 \\
(.454)\end{array}$ & $\begin{array}{l}.816 \\
(.387)\end{array}$ & $\begin{array}{l}.768 \\
(.422)\end{array}$ & $\begin{array}{l}.766 \\
(.423)\end{array}$ & $\begin{array}{l}=1 \text { if crash occurred during the daytime hours } \\
(6: 00 \text { a.m. to } 7: 59 \text { p.m. }),=0 \text { otherwise }\end{array}$ \\
\hline Evening & $\begin{array}{l}.175 \\
(.380)\end{array}$ & $\begin{array}{l}.178 \\
(.383)\end{array}$ & $\begin{array}{l}.133 \\
(.340)\end{array}$ & $\begin{array}{l}.172 \\
(.377)\end{array}$ & $\begin{array}{l}.182 \\
(.386)\end{array}$ & $\begin{array}{l}=1 \text { if crash occurred during the evening hours } \\
(8: 00 \text { p.m. to } 12: 59 \text { a.m. }),=0 \text { otherwise }\end{array}$ \\
\hline Weekend & $\begin{array}{l}.460 \\
(.498)\end{array}$ & $\begin{array}{l}.477 \\
(.500)\end{array}$ & $\begin{array}{l}.414 \\
(.493)\end{array}$ & $\begin{array}{l}.436 \\
(.496)\end{array}$ & $\begin{array}{l}.468 \\
(.499)\end{array}$ & $\begin{array}{l}=1 \text { if crash occurred during the weekend (Friday, } \\
6: 00 \text { p.m. to Monday, } 5: 59 \text { a.m.), }=0 \text { otherwise }\end{array}$ \\
\hline $\mathrm{N}$ & 17,186 & 4,282 & 1,563 & 2,697 & 8,644 & \\
\hline
\end{tabular}

Notes: Means (with SDs in parentheses) are based on unweighted data from the Fatality Analysis Reporting System (2008-2016). 
Table 3. Booster Seats and the Probability of Fatality

\begin{tabular}{|c|c|c|c|c|c|c|}
\hline \multicolumn{7}{|c|}{ Panel I: Without sample selection correction } \\
\hline \multirow[b]{2}{*}{ Booster Seat } & \multicolumn{2}{|c|}{ Full sample (Ages 2-9) } & \multicolumn{2}{|c|}{ Ages 2-5 } & \multicolumn{2}{|c|}{ Ages 6-9 } \\
\hline & $\begin{array}{c}-.117 * * * \\
(.013)\end{array}$ & $\begin{array}{c}-.114 * * * \\
(.014)\end{array}$ & $\begin{array}{c}-.116^{* * *} \\
(.017)\end{array}$ & $\begin{array}{c}-.108 * * * \\
(.019)\end{array}$ & $\begin{array}{c}-.128 * * * \\
(.018)\end{array}$ & $\begin{array}{c}-.122 * * * \\
(.019)\end{array}$ \\
\hline Child Seat & $\begin{array}{c}-.203 * * * \\
(.010)\end{array}$ & $\begin{array}{c}-.190 * * * \\
(.012)\end{array}$ & $\begin{array}{c}-.215^{* * *} \\
(.012)\end{array}$ & $\begin{array}{c}-.187 * * * \\
(.015)\end{array}$ & $\begin{array}{c}-.214 * * * \\
(.020)\end{array}$ & $\begin{array}{c}-.184 * * * \\
(.020)\end{array}$ \\
\hline Seat Belt Only & $\begin{array}{c}-.201 * * * \\
(.008)\end{array}$ & $\begin{array}{c}-.171 * * * \\
(.009)\end{array}$ & $\begin{array}{c}-.201 * * * \\
(.013)\end{array}$ & $\begin{array}{c}-.176^{* * *} \\
(.015)\end{array}$ & $\begin{array}{c}-.192 * * * \\
(.011)\end{array}$ & $\begin{array}{c}-.169^{* * *} \\
(.012)\end{array}$ \\
\hline Probability of death with no restraint & \multicolumn{2}{|c|}{.305} & \multicolumn{2}{|c|}{.320} & \multicolumn{2}{|c|}{.293} \\
\hline \multicolumn{7}{|l|}{ Hypothesis tests (p-values) } \\
\hline Booster Seat $=$ Child Seat & .000 & .000 & .000 & .000 & .000 & .004 \\
\hline Booster Seat $=$ Seat Belt Only & .000 & .000 & .000 & .000 & .000 & .003 \\
\hline Child Seat $=$ Seat Belt Only & .746 & .032 & .156 & .331 & .208 & .382 \\
\hline $\mathrm{N}$ & 17,186 & 17,186 & 7,404 & 7,404 & 9,782 & 9,782 \\
\hline \multicolumn{7}{|c|}{ Panel II: With sample selection correction } \\
\hline & \multicolumn{2}{|c|}{ Full sample (Ages 2-9) } & \multicolumn{2}{|c|}{ Ages 2-5 } & \multicolumn{2}{|c|}{ Ages 6-9 } \\
\hline Booster Seat & $\begin{array}{c}-.090 * * * \\
(.022)\end{array}$ & $\begin{array}{c}-.068 * * * \\
(.020)\end{array}$ & $\begin{array}{c}-.076^{* *} \\
(.030)\end{array}$ & $\begin{array}{c}-.035 \\
(.026)\end{array}$ & $\begin{array}{c}-.105 * * * \\
(.027)\end{array}$ & $\begin{array}{c}-.090^{* * * *} \\
(.026)\end{array}$ \\
\hline Child Seat & $\begin{array}{c}-.092 * * * \\
(.021)\end{array}$ & $\begin{array}{c}-.073 * * * \\
(.019)\end{array}$ & $\begin{array}{c}-.087 * * * \\
(.028)\end{array}$ & $\begin{array}{c}-.053^{* *} \\
(.024)\end{array}$ & $\begin{array}{c}-.092 * * \\
(.031)\end{array}$ & $\begin{array}{c}-.080 * * * \\
(.030)\end{array}$ \\
\hline Seat Belt Only & $\begin{array}{c}-.102 * * * \\
(.021)\end{array}$ & $\begin{array}{c}-.081 * * * \\
(.018)\end{array}$ & $\begin{array}{c}-.099 * * * \\
(.028)\end{array}$ & $\begin{array}{c}-.060 * * * \\
(.022)\end{array}$ & $\begin{array}{c}-.105 * * * \\
(.026)\end{array}$ & $\begin{array}{c}-.094 * * * \\
(.025)\end{array}$ \\
\hline Probability of death with no restraint & \multicolumn{2}{|c|}{.117} & \multicolumn{2}{|c|}{.112} & \multicolumn{2}{|c|}{.121} \\
\hline \multicolumn{7}{|l|}{ Hypothesis tests (p-values) } \\
\hline Booster Seat $=$ Child Seat & .862 & .651 & .440 & .247 & .480 & .626 \\
\hline Booster Seat $=$ Seat Belt Only & .161 & .171 & .089 & .104 & .986 & .713 \\
\hline Child Seat $=$ Seat Belt Only & .081 & .337 & .084 & .502 & .424 & .429 \\
\hline $\mathrm{N}$ & 4,484 & 4,484 & 1,814 & 1,814 & 2,670 & 2,670 \\
\hline Covariates listed in Table 2 & No & Yes & No & Yes & No & Yes \\
\hline
\end{tabular}

* Statistically significant at $10 \%$ level; ** at $5 \%$ level; *** at $1 \%$ level.

Notes: Each column within each panel represents results from a separate OLS regression based on data from the Fatality Analysis Reporting System (2008-2016). The dependent variable is equal to one if the child died in the accident, and is equal to zero otherwise. The estimates should be interpreted as relative to no restraint use. The models that control for the covariates listed in Table 2 also control for state fixed effects, year fixed effects, and interactions between driver injuries and driver seat belt status. The models based on the sample selection correction also control for characteristics of the other vehicle (weight and type) and the other driver (seat belt status, accident history, and prior driving violation charges) involved in the crash. Standard errors, corrected for clustering at the vehicle level, are in parentheses. 
Table 4. Any Child Restraint Device and the Probability of Fatality

\begin{tabular}{|c|c|c|c|}
\hline With sample selection correction & $\begin{array}{l}\text { Full sample } \\
\text { (Ages 2-9) }\end{array}$ & Ages 2-5 & Ages 6-9 \\
\hline Any Child Restraint Device & $\begin{array}{c}-.079 * * * \\
(.018)\end{array}$ & $\begin{array}{c}-.068 * * * \\
(.024)\end{array}$ & $\begin{array}{c}-.090 * * * \\
(.025)\end{array}$ \\
\hline Seat Belt Only & $\begin{array}{c}-.084 * * * \\
(.018)\end{array}$ & $\begin{array}{c}-.073 * * * \\
(.024)\end{array}$ & $\begin{array}{c}-.094 * * * \\
(.025)\end{array}$ \\
\hline Probability of death with no restraint & .117 & .112 & .121 \\
\hline $\begin{array}{l}\text { Hypothesis test ( } \mathrm{p} \text {-values) } \\
\text { Any Child Restraint Device }=\text { Seat Belt Only }\end{array}$ & .230 & .444 & .575 \\
\hline $\mathrm{N}$ & 6,391 & 3,375 & 3,016 \\
\hline
\end{tabular}

* Statistically significant at $10 \%$ level; ** at $5 \%$ level; *** at $1 \%$ level.

Notes: Each column represents results from a separate OLS regression based on data from the Fatality Analysis Reporting System (2008-2016). The dependent variable is equal to one if the child died in the accident, and is equal to zero otherwise. The estimates should be interpreted as relative to no restraint use. All models control for the covariates listed in Table 2, state fixed effects, year fixed effects, interactions between driver injuries and driver seat belt status, characteristics of the other vehicle (weight and type) and the other driver (seat belt status, accident history, and prior driving violation charges) involved in the crash. Standard errors, corrected for clustering at the vehicle level, are in parentheses. 
Table 5. Booster Seats and the Probability of Fatality by Subsamples of the Data for Children Ages 2-9

With sample selection correction

\begin{tabular}{|c|c|c|c|c|c|c|c|c|}
\hline & $\begin{array}{l}\text { Luxury } \\
\text { vehicles }\end{array}$ & $\begin{array}{l}\text { Non-luxury } \\
\text { vehicles }\end{array}$ & Cars & $\begin{array}{l}\text { Light } \\
\text { trucks }\end{array}$ & $\begin{array}{c}\text { Newer } \\
\text { vehicles }\end{array}$ & $\begin{array}{c}\text { Older } \\
\text { vehicles }\end{array}$ & $\begin{array}{l}\text { Direct front } \\
\text { impact }\end{array}$ & $\begin{array}{l}\text { Other } \\
\text { impact }\end{array}$ \\
\hline Booster Seat & $\begin{array}{l}-.081^{*} \\
(.046)\end{array}$ & $\begin{array}{c}-.060 * * * \\
(.022)\end{array}$ & $\begin{array}{l}-.026 \\
(.041)\end{array}$ & $\begin{array}{c}-.083 * * * \\
(.021)\end{array}$ & $\begin{array}{c}-.077 * * * \\
(.028)\end{array}$ & $\begin{array}{l}-.045 \\
(.028)\end{array}$ & $\begin{array}{c}-.087 * * * \\
(.024)\end{array}$ & $\begin{array}{l}-.003 \\
(.037)\end{array}$ \\
\hline Child Seat & $\begin{array}{l}-.041 \\
(.045)\end{array}$ & $\begin{array}{c}-.075 * * * \\
(.021)\end{array}$ & $\begin{array}{l}-.021 \\
(.036)\end{array}$ & $\begin{array}{c}-.092 * * * \\
(.022)\end{array}$ & $\begin{array}{c}-.070 * * \\
(.027)\end{array}$ & $\begin{array}{c}-.068 * * * \\
(.025)\end{array}$ & $\begin{array}{c}-.082 * * * \\
(.025)\end{array}$ & $\begin{array}{l}-.040 \\
(.030)\end{array}$ \\
\hline Seat Belt Only & $\begin{array}{l}-.072 * \\
(.043)\end{array}$ & $\begin{array}{c}-.078^{* * * *} \\
(.020)\end{array}$ & $\begin{array}{l}-.061^{*} \\
(.034)\end{array}$ & $\begin{array}{c}-.089 * * * \\
(.021)\end{array}$ & $\begin{array}{c}-.091 * * * \\
(.028)\end{array}$ & $\begin{array}{c}-.061 * * * \\
(.022)\end{array}$ & $\begin{array}{c}-.089 * * * \\
(.022)\end{array}$ & $\begin{array}{l}-.055^{*} \\
(.030)\end{array}$ \\
\hline $\begin{array}{l}\text { Probability of death with no } \\
\text { estraint }\end{array}$ & .158 & .113 & .124 & .113 & .116 & .118 & .112 & .129 \\
\hline Hypothesis test (p-values) & & & & & & & & \\
\hline Booster Seat $=$ Child Seat & .088 & .256 & .879 & .379 & .625 & .222 & .692 & .142 \\
\hline Booster Seat $=$ Seat Belt Only & .658 & .106 & .151 & .533 & .186 & .376 & .849 & .018 \\
\hline Child Seat $=$ Seat Belt Only & .093 & .762 & .034 & .744 & .053 & .535 & .530 & .235 \\
\hline J & 815 & 3,635 & 1,355 & 3,129 & 2,428 & 2,056 & 3,005 & 1,463 \\
\hline
\end{tabular}

* Statistically significant at $10 \%$ level; ** at $5 \%$ level; *** at $1 \%$ level.

Notes: Each column represents results from a separate OLS regression based on data from the Fatality Analysis Reporting System (2008-2016). The dependent variable is equal to one if the child died in the accident, and is equal to zero otherwise. The estimates should be interpreted as relative to no restraint use. All models control for the covariates listed in Table 2, state fixed effects, year fixed effects, interactions between driver injuries and driver seat belt status, characteristics of the other vehicle (weight and type) and the other driver (seat belt status, accident history, and prior driving violation charges) involved in the crash. Standard errors, corrected for clustering at the vehicle level, are in parentheses. 


\section{Appendix Table 1. Booster Seats and the Probability of Fatality (Finer Breakdowns by Age)}

Panel I: Without sample selection correction

Booster Seat

\begin{tabular}{ccc} 
Ages $2-3$ & & Ages $4-6$ \\
\cline { 1 - 1 }$-.117^{* * *}$ & & $-.095^{* * *}$ \\
$(.033)$ & & $(.020)$ \\
$-.209 * * *$ & & $-.164 * * *$ \\
$(.023)$ & & $(.018)$ \\
$-.189 * * *$ & & $-.163^{* * *}$ \\
$(.023)$ & & $(.015)$
\end{tabular}

Probability of death with no restraint

.340

.290

.302

Hypothesis tests (p-values)

Booster Seat $=$ Child Seat

.001

.016

.000

.030

Booster Seat $=$ Seat Belt Only

.273

.000

.336

Child Seat $=$ Seat Belt Only

3,363

.943

.046

$\mathrm{N}$

6,257

7,566

Panel II: With sample selection correction

Booster Seat

\begin{tabular}{c} 
Ages 2-3 \\
\hline-.018 \\
$(.039)$ \\
-.024 \\
$(.032)$ \\
$-.059^{*}$
\end{tabular}

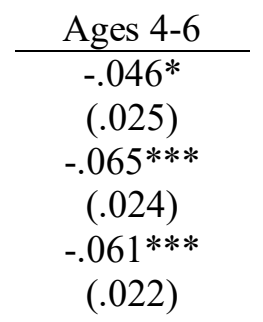

Ages 7-9

$-.114 * * *$

Child Seat

.138

.081

$-.083^{* * *}$

$-.101 * * *$

Seat Belt Only

.138

Hypothesis tests (p-values)

Booster Seat $=$ Child Seat

.809

.216

.245

Booster Seat $=$ Seat Belt Only

.155

Child Seat $=$ Seat Belt Only

.040

.229

.313

.714

.478

$\mathrm{N}$
$*$ Statistically significant at $10 \%$ level; $* *$ at $5 \%$ level; $* * *$ at $1 \%$ level.

1,565

2,087

Notes: Each column within each panel represents results from a separate OLS regression based on data from the Fatality Analysis Reporting System (2008-2016). The dependent variable is equal to one if the child died in the accident, and is equal to zero otherwise. The estimates should be interpreted as relative to no restraint use. All models control for the covariates listed in Table 2, state fixed effects, year fixed effects, and interactions between driver injuries and driver seat belt status. The models based on the sample selection correction also control for characteristics of the other vehicle (weight and type) and the other driver (seat belt status, accident history, and prior driving violation charges) involved in the crash. Standard errors, corrected for clustering at the vehicle level, are in parentheses. 


\section{Appendix Table 2. Booster Seats and the Probability of Fatality Based on More Inclusive Sample Selection Corrections}

\begin{tabular}{|c|c|c|c|}
\hline \multicolumn{4}{|c|}{$\begin{array}{l}\text { Panel I: With sample selection correction that also includes crashes where own driver died } \\
\text { Full sample }\end{array}$} \\
\hline Booster Seat & $\begin{array}{c}-.075 * * * \\
(.020)\end{array}$ & $\begin{array}{l}-.036 \\
(.029)\end{array}$ & $\begin{array}{c}-.111 * * * \\
(.026)\end{array}$ \\
\hline Child Seat & $\begin{array}{c}-.111 * * * \\
(.018)\end{array}$ & $\begin{array}{c}-.097 * * * \\
(.024)\end{array}$ & $\begin{array}{c}-.116^{* * *} \\
(.029)\end{array}$ \\
\hline Seat Belt Only & $\begin{array}{c}-.103 * * * \\
(.016)\end{array}$ & $\begin{array}{c}-.080 * * * \\
(.023)\end{array}$ & $\begin{array}{c}-.122 * * * \\
(.021)\end{array}$ \\
\hline Probability of death with no restraint & .200 & .199 & .201 \\
\hline \multicolumn{4}{|l|}{ Hypothesis test (p-values) } \\
\hline Booster Seat $=$ Child Seat & .018 & .002 & .829 \\
\hline Booster Seat $=$ Seat Belt Only & .036 & .031 & .494 \\
\hline Child Seat $=$ Seat Belt Only & .486 & .234 & .780 \\
\hline $\mathrm{N}$ & 6,163 & 2,554 & 3,609 \\
\hline
\end{tabular}

Panel II: With sample selection correction that also includes crashes where other driver was charged with a violation

\begin{tabular}{|c|c|c|c|}
\hline ( & $\begin{array}{l}\text { Full sample } \\
\text { (Ages 2-9) }\end{array}$ & Ages 2-5 & Ages 6-9 \\
\hline Booster Seat & $\begin{array}{c}-.094 * * * \\
(.021)\end{array}$ & $\begin{array}{c}-.066^{* *} \\
(.031)\end{array}$ & $\begin{array}{c}-.125^{* * *} \\
(.027)\end{array}$ \\
\hline Child Seat & $\begin{array}{c}-.133 * * * \\
(.019)\end{array}$ & $\begin{array}{c}-.126 * * * \\
(.027)\end{array}$ & $\begin{array}{c}-.128 * * * \\
(.030)\end{array}$ \\
\hline Seat Belt Only & $\begin{array}{c}-.123 * * * \\
(.018)\end{array}$ & $\begin{array}{c}-.115 * * * \\
(.026)\end{array}$ & $\begin{array}{c}-.132 * * * \\
(.023)\end{array}$ \\
\hline Probability of death with no restraint & .201 & .201 & .200 \\
\hline \multicolumn{4}{|l|}{ Hypothesis test (p-values) } \\
\hline Booster Seat $=$ Child Seat & .008 & .003 & .916 \\
\hline Booster Seat $=$ Seat Belt Only & .026 & .020 & .664 \\
\hline Child Seat $=$ Seat Belt Only & .364 & .456 & .839 \\
\hline $\mathrm{N}$ & 5,156 & 2,109 & 3,047 \\
\hline
\end{tabular}

* Statistically significant at $10 \%$ level; ** at $5 \%$ level; *** at $1 \%$ level.

Notes: Each column within each panel represents results from a separate OLS regression based on data from the Fatality Analysis Reporting System (2008-2016). The dependent variable is equal to one if the child died in the accident, and is equal to zero otherwise. The estimates should be interpreted as relative to no restraint use. Controls include the covariates listed in Table 2, state fixed effects, year fixed effects, interactions between driver injuries and driver seat belt status, characteristics of the other vehicle (weight and type) and the other driver (seat belt status, accident history, and prior driving violation charges) involved in the crash. Standard errors, corrected for clustering at the vehicle level, are in parentheses. 